\title{
Modular sovereignty, security, and debt: The Excessive Deficit Procedure of the European Union
}

\section{Andreas Langenohl}

Justus Liebig University of Giessen, Germany

\begin{abstract}
The Excessive Deficit Procedure (EDP) is a political mechanism that aims at 'multilevel governance' of state indebtedness in the European Union. As such, it has become the concern of research that asks how sovereignty becomes articulated in this process. This article approaches this question through the conceptualization of a modular notion of sovereignty elaborated through a discussion of work on the finance-security nexus. The article argues that existing accounts of the formation of sovereign power in relation to state debt can be combined into a notion of modular sovereignty when seen through the prism of critiques of contractualism that take issue with liberal notions of state sovereignty and credit security. This way, the indebted state becomes visible as the referent object of multiple, and potentially contradictory, invocations of sovereignty as exercised in the EDP. First, it figures as the seat of budget sovereignty, holding its social substrate liable for its debts while ignoring inequalities in that substrate. Second, it is appealed to, within a biopolitical rationality, as the sovereign guarantor of the financial wellbeing of its population. Third, it is seen as the executor of financial wisdom that is mobilized in struggles between different levels of financial governance in the EDP.
\end{abstract}

\section{Keywords}

European Union, Excessive Debt Procedure, sovereignty, sovereign debt, contractualism

\section{Introduction}

The sovereign debt crisis in the European Monetary Union (EMU) has increased concerns over the intersection of state debt, political sovereignty, and societal security. The present article seeks to contribute to this debate in a way that avoids two of its prominent preoccupations: first, that the issue of debt needs to be addressed because of its importance to the dynamics of the current crisis; and second, that the issue of sovereignty primarily concerns relocations of sovereign powers between different levels of EU and EMU governance (i.e., the

\section{Corresponding author:}

Andreas Langenohl, Department of Sociology, Justus Liebig University Giessen, Karl-Glöckner-Str 21 E, D-35394 Giessen, Germany. Email: andreas.langenohl@sowi.uni-giessen.de 
supranational, intergovernmental, and state levels). Instead I will argue, first, that in the EU and EMU, state debt informs articulations of sovereignty in rather inconspicuous ways, taking the Excessive Deficit Procedure (EDP) as an example; and second, that what is at stake in these articulations are multifaceted and variegated understandings of sovereignty in their relations to debt that may best be termed 'modular'.

To this end, the article engages with recent finance-security literature dealing with understandings of sovereign power that seem to offer a contradictory picture at first sight. Nina Boy $(2014,2015)$ sees a critical source of sovereign power in sovereign credit that, while partly governed through governmentality, represents a form of centralized power not captured by Foucault's decentralizing analytics. Paul Langley (2013, 2015), on the other hand, sees sovereign power through a Foucauldian lens, in the context of a biopolitical rationality to govern the financial wellbeing of populations. In this article I argue that, rather than contradictory, these perspectives may be integrated into a notion of modular sovereign power that is capable of encompassing and interrelating the following dimensions of sovereignty: the 'accreditation' of political authority together with sovereign creditworthiness; a biopolitically motivated invocation of the state as being responsible for the financial wellbeing of the population; and the invocation of the state as a 'Leviathan' vis-à-vis its own population, that is, the flip side of a contractualist understanding both of sovereignty and sovereign debt. I then illustrate this argument through a close analysis of the case of the EDP. As a central European institution that has articulated sovereignty over the past two decades, the EDP offers critical insights into a notion of sovereign power at the intersection of contractualism and indebtedness.

The article starts out with a discussion of Boy's notion of 'accreditation' and 'sovereign safety' in order to flesh out the imaginary dimension of sovereign power and creditworthiness. This dimension will then be contextualized through critiques of contractualism that point to the societal undercurrents of liberal sovereign imaginations, which are social hierarchies and asymmetrical obligations respectively. This discussion specifies both sovereignty and debt as effects of contractualism. On the basis of these discussions, I then develop a notion of 'modular sovereignty' that is capable of fleshing out variegated materializations of the entanglement of sovereignty, contractualism, and debt. The article then moves to its empirical concern: the constitution of the sovereignty of those states that, within the EU, become problematized in terms of their budget deficits and their debts, and are subjected to supranational interventions through the framework of the EDP. I argue that the EDP is a particularly apt case in point not only because it represents a completely 'normal' procedure in EU governance, but also because it condenses broader tendencies in the articulation of sovereignty at the intersection of contractualism and indebtedness.

\section{Sovereign accreditation: The state as the horizon of financial activity}

In recent years, there has been a growing interest in the question of how financial investiture has enabled states to gain a 'sovereign' reach over societies, and how finance has contributed to creating imaginations of a match between society and polity. Recent studies have demonstrated how modern forms of government debt emerged alongside an imaginary of society as related to the polity (Boy, 2014, 2015). From this perspective, sovereign bonds and social bonds are inseparable. As the state became the seat of sovereign safety, so society was imagined as an assembly of investors focused on the state. ${ }^{1}$ Gustav Peebles (2008) has demonstrated how at the end of the nineteenth century, hoarders were encouraged to transfer 
their assets to national savings banks, which focused their financial calculus on the state and its currency. With a view to the recent financial crisis, Langley (2015: 15) has argued that the crisis was interpreted in such a way as to center "the agency of crisis governance upon the institution of the state", for instance, through the invocation of the state's responsibility to act as a lender of last resort. The state as a seat of sovereignty is thus evoked through a set of "sovereign techniques" as part of an array of "sovereign, disciplinary, and biopolitical modalities of power" (Langley, 2015: 173).

From these instances, a cultural economy approach (Langley, 2015: 2-5) that asks through which practices the state becomes culturally invested with sovereignty with respect to economic and financial processes moves into sight. The concern of this article, along these lines, is to look at how sovereign debt-related practices in the EU have contributed to imbuing the state with sovereignty, and to interrogate the precise nature of sovereignty entailed therein. In the Foucauldian tradition, sovereignty has long been seen as a relic from a past order of governance that has since been supplanted first by discipline, and later by governmentality. Although Foucault himself has repeatedly pointed out that the three modes of governance or of power - sovereignty, discipline, governmentality - do not replace each other but remain salient, to varying degrees in different constellations (Foucault, 2007: 107; cf. also Collier 2011), at the same time he seemed to invite a reading according to which, in contemporary societies, the governmental mode of power has become dominant (as in Miller and Rose, 1990). And indeed, the way that his lecture series at the Collège de France was structured could be read as claiming a linear sequence from sovereignty to discipline and finally to governmentality. For instance, in his discussion of 'security' as a major governmental dispositif in contemporary societies, Foucault argues that the governmental type of social control, unlike the earlier types of sovereignty and discipline, neither prescribes nor controls behavior as sovereignty and discipline would have. Instead, the milieu of the targeted subjects is manipulated and modified so that the desired results emanate from the subjects' own qualities and actions (Foucault, 2007).

The shift from discipline to governmentality also marked a move through which Foucault increasingly denied the state, or any other form of centralized political power, the conceptual capacity to account for contemporary shifts in the structuring of society (Dean, 1994; Boy, 2015). This argument was based on his conception of power as diffused throughout society (a stance which united his understanding of disciplinary power with that of governmental power) (Foucault, 2003: 23-41; Boy, 2015: 538-39). According to Boy (2015: 539), this tendency to bypass the state is paralleled by "the fact that public credit [...]'disappeared' from the focus of cultural critical discourses" in Britain over the eighteenth and nineteenth centuries. Yet, it is in public credit that the imaginary nature of the national collective as the foundation of state sovereignty parallels the fiction of public creditworthiness (Boy, 2014: 11-12):

Foucault's emphasis on divesture and discredit of the centralized power of the state runs somewhat counter to the very successful investiture and accreditation that sovereign credit implies. (Boy, 2015: 539, emphasis in original)

In her reconstruction of the validity structure of 'public credit' in Britain since the late seventeenth century, Boy points out that the emergence of a public debt was, from the very start, challenged by criticisms regarding the mysterious basis of the state's creditworthiness and thus the value of its bonds. Yet these cultural critiques not only failed to affect the emerging liquidity of sovereign bonds, they also produced a notion of intersubjectivity that only further legitimized public credit. This, according to Boy, revealed the "singular phenomenon of 
an effective fiction and its ineffective denunciation" (Boy, 2014: 312, author's translation). Contra Foucault, the state becomes the point of crystallization for attributions of creditworthiness and the projection screen of a "collective accreditation" (Boy, 2014: 310, author's translation).

The discursive viability and persuasiveness of this imagination of the sovereign state as financial guarantee must itself be secured. According to Boy (2015: 534-38), who terms this imagination "sovereign safety", government debt has traversed a remarkable imaginary career: While lending to the government counted as the riskiest of financial investments in the context of medieval sovereigns, over the centuries certain government bonds have become seen as 'safe havens' which come unsecured, that is, without any indication what their collateral consists of. Moreover, it has been argued that state sovereignty, which also crucially includes fiscal autonomy, is based on a state's capacity to shield its debts from interrogation. Since the twentieth century, this has typically been achieved through international bond markets. Markets for sovereign bonds can neutralize the potential for critical questions as to the substance of the collateral for sovereign debt, because they deflect and redirect such questions onto the completely different problem of whether it is possible, likely, and profitable to find buyers for that debt (Priddat, 2014; Langenohl, 2015). The market circulation of government bonds, as long as it functions, thus tends to render doubts as to the substance of such debt (that is, the state collateral) pointless and ineffective.

\section{Sovereign security, the securing of debt, and contractualism}

As Boy (2014) argues, sovereign creditworthiness and the fictive nature of the validity structures underlying it have to be seen in the historical context of a transformation of the legitimacy of political rule in modernity more broadly. Thus, "both public credit and political authority ... converge as effective fictions" (Boy, 2015: 541), which is to say, they are produced through a process of collective accreditation that masks its own origin. It is from this process that credit and authority emerge as relatively immune to exposure as to their insubstantiality. Sovereign credit, thus, appears as a component of a more general type of political legitimacy based on the pervasiveness of imaginations that can never be verified in experience (see Hebekus et al., 2003). In this section, I will extend this argument, which operates on the level of collective imagination, by a perspective that specifies security as a type of social relationship that underpins both political authority and financial investiture. This discussion will contribute to discerning the security-finance nexus in the accreditation of the sovereign state as an indebted state, showing the common mechanisms in the securing of sovereign power and the securing of credit.

\section{Sovereign security and contractualism}

In liberal thought, sovereignty is usually equated with collective security in a polity, as opposed to a 'war of all against all' from which a certain complicity between the fetishization of security and the liberal insistence on individual liberty is deduced. For instance, Marc Neocleous (2007) reproaches liberal political theory's grounding in individualism, which is a crucial precondition for Hobbesian conceptions of sovereignty insofar as it is based on a contract voluntarily entered into by individuals preoccupied with their own security. This paradoxically undermines those individuals' potential to engage in mutual agreements without securitizing those agreements. For liberalism, Neocleous concludes, individualism can be the foundation 
of political structures only at the cost of a policing of those same individuals. In this, he shares a more general critique of the exceptionalist political logic that Agamben (2002) argues forms the basis of democratic liberalism as a doctrine of modern societies. According to his argument, liberal, law-based sovereignty constitutes itself through the positing of an outside sphere that is, however, violently integrated into processes of political exclusion that target the 'bare lives' of outsiders.

However, criticisms of liberal-contractualist models of sovereignty tend to gloss over the fact that already in Hobbes there is a clear engagement with the questions of whose security needs to be safeguarded and at whose cost. Hobbes did not juxtapose the condition of peace in the sovereign state with a state of war but rather with a state of insecurity (that is, of potential violence). According to Foucault's reading of Hobbes, this potential for violence appeared particularly scandalous as it threatened not only the weak, but also powerful persons who, under conditions of absent sovereign power, were vulnerable to potentially effective attacks by relatively powerless people (Foucault, 2003: 91-92). In other words, the real scandal of the 'war of all against all' as a major allegory in the Leviathan, was that hierarchical relations are not obeyed as read from the apparent and seemingly legitimate allocation of power in society (cf. Foucault, 2003: 97).

The safeguarding of security and peace was, for Hobbes, tightly circumscribed by considerations of how to stabilize hierarchical social orders. This is testified to by Philipp Manow (2011: 23-33), who argues that Hobbes conceived of the 'war of all against all' not as a war between individuals, but instead between families or households within which a patriarchal hierarchy structured obligations so that female obedience was exchanged for male protection. According to Manow, this seemingly natural patriarchy and subordination had to be replicated in the relation between state and society; for order and security to be achieved, it was tantamount to secure the authority of those who dominated the social hierarchy. In this sense, state sovereignty had to be achieved for the same reason that patriarchal domination had to be secured.

Accordingly, mainstream readings of Hobbes, which see the foundational scene of state sovereignty in a voluntary contract among subjects (for instance, Skinner, 2008), might unwittingly replicate a performative gesture on which modern political sovereignty was grounded. They replay the broadening out of sovereignty's imaginary basis to the citizenry as the flipside of a generalization of security concerns that, as Hobbes implied, were most vital for those whose strength did not guarantee their safety and who were simultaneously interested in maintaining the social hierarchy that privileged them. The seemingly general contractual agreement among subjects to abandon their power for the sake of collective security favors powerful and dominating subjects much more than powerless and subordinate ones. The foundational scene of the Leviathan - not in Hobbes, but in many misreadings of the notion of a 'war of all against all' - builds up an illusionary picture of a society whose political nature is seemingly free from hierarchical relations.

The contractualist reading has it that equal individuals enter into a contract with each other to surrender any claim to violence to the state, which in turn produces everybody's security and safety. The state, according to this reading, is an effect of a contract among free and equal individuals who, as it were, invest in the state; and, as Neocleous (2007) reminds us, the state, once in power, holds these individuals in 'freedom', understood as isolation and responsibilization - that is, securitization. Yet there is another reading possible, according to which the security and safety guaranteed by the state stabilizes hierarchies in society, because some individuals have a greater interest in particular kinds of security and safety than others. At the same time, the contractualist reading glosses over these hierarchies as it renders 
society as a sum of individuals (Foucault, 2003: 94, 97). While Foucault in later works (2007) capitalized on 'security' as the signal concern of the governmental mode of power, his reading of Hobbes uncovers a notion of sovereignty which results from a state of affairs in which "there is nothing to provide security, to establish differences, and finally to give the strength to one side and not the other" (Foucault 2003: 93). Sovereignty, then, would bring about not only security for all, but also differentiation and hierarchization - with the latter point being systematically effaced in the contractualist reading. The next subsection identifies a similarly effaced constitutive function for hierarchy in the contractual form of credit relationships.

\section{Securing debt through contractualism}

The Eurozone's sovereign debt crisis has sparked a debate on the social ontology and effects of debt that has raised contributions from various disciplines (see, for instance, Macho 2014). Debt has also emerged as a major theoretical touchstone in cultural economy. However, it is in cultural anthropology where the issue of debt and indebtedness has the most significant and conceptually broadest tradition. In particular, the work of Marcel Mauss (1954) has been rediscovered as a source of inspiration by at least three generations of anthropologists (cf. Caillé, 2008; Adloff and Mau, 2005; Adloff, 2016). Among other things, Mauss's work has been invoked in order to demonstrate that the conceptual figure of a rationally self-interested homo oeconomicus, and with it contractualist understandings of society, are untenable because exchange involves social obligations that cannot be contractually guaranteed. To give a gift involves the possibility that the gift is not reciprocated, thus resulting in a loss on the side of the giver. To accept a gift, conversely, means not only a net gain but also involves accepting an, if unarticulated, obligation to return a counter-gift. Finally, to return that countergift does not simply clear the balance between giver and receiver, but is imbricated with complex rationalities as to the adequateness of the counter-gift in relation to the original gift which defy a purely utilitarian rationality, which would order not to return anything. Gift exchange, therefore, defies the paradigm of contractualism because each move involves a specific uncertainty that surpasses a rational and rationed conception of self-interest. Instead, the logic of the gift involves a degree of exposing oneself to the cooperation of the other, which cannot be completely secured.

More recent discussions around the concept of the gift highlight the mechanisms through which gift-centered relationships can transform into debt-centered relationships, with significant consequences for the hierarchical restructuring of those relationships. One important element to this transformation is the contractual form. Within this context, David Graeber has placed emphasis on the period of time between the reception of a gift and the (potential) return of a counter-gift, arguing that this interval resembles a condition that enables sociality through social obligations in the first place. The point about the gift is not that it is based on strict reciprocity, whether the subjects realize it or not (as Bourdieu [1997] had claimed), but that it creates obligations as long as it is not returned. In other words, the gift is emblematic not of reciprocity, but of obligation-based sociality (Graeber, 2001: 217-28). In his more recent writings, Graeber (2011) expands this line of thought into a fully-fledged anthropology of debt. He distinguishes between two ideal-typical forms of social obligations, which he traces in their recurrent articulations over a very longue durée. On the one hand, there is credit, that is, a form of sociality in which individuals are bound together through a net of obligations. The fact that A owes B, in this configuration, is always embedded in a much broader range and variety of obligations. At the same time, it remains a concrete obligation, 
that is, an obligation that cannot be circulated or passed on to other individuals although they may be open to negotiation. On the other hand, there is debt, that is, an obligation isolated from the net of obligations, which is non-negotiable on the side of the debtor, and which can be passed on by the creditor to another person.

Importantly, the vehicle for such isolation is the contract. The contract enables several things at once. First, inserted into a legal system that demands that contracts be fulfilled, the contract is the immediate security of any given debt - a security which, in turn, presupposes the existence of a political sovereign that can enact that security in the form of law. Second, the contract crafts a formally symmetrical relationship between debtor and creditor in the form of a legal, effective fiction. As any contract made without the consent of all parties is rendered void, the voluntary consent of all parties has to be presupposed in order to bring the debt's security into existence. Third, however, the relationship created by the loan contract is hierarchical and asymmetrical as long as the loan is not paid back (Graeber, 2011: 120-22).

So, in contrast to credit, contractualized debt facilitates a legal and formal pledge to be 'paid back', thus securing the loan. It is Graeber's historical argument that social relations of debt tended to replace those of credit whenever obligations started to circulate - in other words, debt relations were bound to the emergence of money and of competitive markets (Graeber, 2011: 1-19, 223-50). The concept of debt announces the emergence of hierarchies and domination from the market circulation of obligations whose foundational moment is the asymmetry between debtor and creditor - i.e., that the creditor can pass on the obligation (for instance, through selling the debt), with the debtor retaining little control over whom he or she actually owes. At the same time, the contractual form of the debt obligation glosses over and makes that hierarchy symbolically disappear.

Thus, Graeber comes close to articulating a paradox. On the one hand, obligations are indispensable to sociality; yet, on the other hand, as soon as they ossify into debt, they tend to have rather divisive, and violent, effects. The emergence of debt, as opposed to credit, paved the way for the most brutal ways of reclaiming a debt, including slavery (Graeber, 2011: 165210). The transformation of credit into debt thus comes along with an introduction of hierarchical social relations into a fundamental mode of sociality, while at the same time that hierarchy is effaced by way of the contractual legal shape of the relation. Credit and debt oscillate between obligations as a precondition for sociality, and the hierarchization and ossification of social relations.

\section{The non-neutrality of the contractual form}

The contractual form is specific to the imagination of political sovereignty and security as arising from a social contract, as well as to the securing of credit in the form of debt. But at the same time, the contractual form is neutral with respect to neither liberal sovereign security nor credit security. Contracts constitute each through their capacity to deemphasize and efface those social hierarchies and power differentials on which both sovereign security and credit security are grounded.

This is an important amendment to Boy's argument about the collective accreditation of political authority and public credit because it highlights the significance of a social substrate that is presupposed and at the same denied in such accreditation. While Boy's argument operates at the level of collective imagination, pointing to the fictions that organize both political authority and sovereign creditworthiness, Foucault's and Graeber's arguments disclose those fictions as being implicitly based on particular types of social relationships, 
namely, those characterized by hierarchization (societal security in the interest of the powerful) and by a disembedding from broader social contexts (credit security in the form of debt). This has implications for a more general conceptualization of security in its role of constituting both sovereignty and creditworthiness, moving into sight social structures as effaced and yet presupposed in claims to sovereignty and credit security.

This insight will guide my analysis of the specific forms and formats of sovereignty to be met in the European Union under conditions of looming government debt crises. Given the strongly contractual structure of the European Union and its governance mechanisms, this section has provided us with an epistemology that highlights asymmetries and hierarchies underlying contractualist claims to sovereign security as well as to financial security. In order to expose and dissect these, however, a conceptual methodology is needed that unpacks the notion of sovereignty further in order to show how its components are reassembled in the contemporary constellation of crisis in the EU.

\section{Modular sovereignty}

The notion of 'sovereign credit' and its implication for understanding the nature of collective accreditation of the state as sovereign, now, has to be brought into the context of recent discussions on the security-finance nexus that reconstruct the notion of sovereign power in complex ways. In general, one can say that this body of literature views sovereignty as a mode of power that is constituted through heterogeneous processes and materializes in distributed forms. This view is based on a reading of Foucault, which argues that sovereign power often materializes in interrelation and configuration with other modes of power, that is, governmental and disciplinary power (Collier, 2011). In this section, I will expand on this discussion in order to circumscribe my conceptual take.

For Nina Boy (2015: 539), the viability of sovereign credit presents itself as an "investiture [that] hinges on the collective acceptance expressed in the voluntary purchase of government bonds". She makes the case for a reconstruction of the power mode indicated by the existence of sovereign credit as focused on a "centralized form of state power ... whose 'mythicized abstraction' is of great significance" (Boy, 2015: 539). As such, Boy directly addresses the state as the object of investiture. In a slight variation, Paul Langley (2015), who has analyzed Anglo-American responses to the financial crisis starting in 2007, conceptualizes 'sovereign power' as the attribution of a specific responsibility for anti-crisis measures to institutions that have historically been integral to the modern state's governance of the economy, such as central banks. The invocation of these institutions during the crisis has spurred their public legitimacy to define norms for economic processes, thus placing them in a Foucauldian horizon of sovereign power. However, their 'sovereignty' materializes within a complex and heterogeneous dispositif of power that is, not least, characterized by governmental and biopolitical rationalities, such as those pertaining to "the future wealth and well-being of the population" (Langley, 2015: 178). In other words, 'sovereign power', being understood as a norm-setting mode of power wielding public legitimacy, forms as a product of the biopolitical rationality of the population's financial security.

In contrast, Louise Amoore (2013: 13-18) reads sovereign power through Giorgio Agamben's reconstruction, departing from Carl Schmitt's co-foundation of sovereignty and exception. According to Agamben (2005), sovereignty consists in the setting of norms outside of the realm of any existing juridical system or control. Sovereignty, thus, is precisely not about public legitimacy but about the capability to initiate decisions that enshrine norms into social practices (see also de Goede, 2012: 48-49). Interestingly, Amoore applies this reconstruction 
to the formulation of standards in security-related practices by experts, who are not politically legitimized, yet still authorized to make decisions upon norms guiding security analytics and practices. Thus, like in Langley, sovereignty co-emerges with governmental or disciplinary forms of power (Amoore, 2013: 66-67), yet not in the sense of collective accreditation of sovereign power but, rather, in the sense of having the ability to initiate decisions that enact norms.

One may channel these complexities of the notion of sovereignty back into Boy's analyses of 'sovereign credit' and 'sovereign safety' as modes of accreditation. 'Accreditation' refers to an invocation of the polity as that institution which enjoys, as one could say, a 'last resort' function in terms of financial security. Accreditation can also be understood, with Langley, as a sovereignty function that becomes effective precisely through being coupled with biopolitical rationalities. Indeed, in Langley's (2015: 166) analysis of the Anglo-American financial crisis, governance obtains through "the securing of a valued form of life - a mode of existence in which the opportunities for wealth and well-being, apparently afforded by uncertain circulations, are embraced by investors and entrepreneurs".

Moreover, with respect to Amoore, we may understand the sovereignty of this 'last resort' function as the pre-juridical establishment of a certain normality. This point is indirectly seconded by Langley, who points out, referring to Kindleberger (1996: 146), that the notion of 'last resort' has a juridical genealogy, referring to "the legal jurisdiction beyond which it is impossible to take an appeal". The notion of 'last resort' thus points to a form of financial or legal guarantee which itself is not guaranteed by any 'higher' authority - and thus has a certain proximity to Agamben's reading of sovereignty as referring to a norm-setting gesture that is itself not normatively circumscribed. 'Sovereign safety', in other words, establishes a foundational norm potentially intertwined with biopolitical rationalities, which at the same time constitutes the state as an instance of financial as well as political security that cannot be reduced to further instances lying behind it.

We thus arrive at a conception of sovereignty that retains the mark of collective accreditation and investiture of the state rightly stressed by Boy, but is also capable of connecting it to biopolitical and Schmittean perspectives. ${ }^{2}$ State sovereignty is the result of an accreditation, but that accreditation is neither autonomous nor exclusive of other modes of power. Taking up a notion introduced in passing by Amoore, ${ }^{3}$ I term this construction of sovereignty 'modular', that is, a mode of power that variably combines different elements, trajectories and appliances of power into an invocation of sovereignty (see also Langley, 2015: 173-74). The next section will dissect these modular actualizations of state sovereignty within a context in which sovereignty seems to be extremely circumscribed by the contractual form.

\section{Governing debt in the EU: The case of the Excessive Debt Procedure}

The Excessive Deficit Procedure (EDP) of the EU was introduced with the Maastricht Treaty, but has acquired a new functionality in the context of Europe's sovereign debt crises. As a device of contemporary debt governance, the EDP rearticulates state sovereignty in important ways. In particular, we are seeing the accreditation of the indebted state as a seat of modular sovereignty through formal procedures within the framework of the EDP. This accreditation works along the lines of different rationalities that each articulate different components of modular sovereignty. 


\section{The EDP as a device to govern debt}

The EDP is a device of supranational governance going back to the Stability and Growth Pact (SGP), entering into force within the framework of the Maastricht Treaty in 1997. As part of the SGP, convergence goals and stability criteria were formulated, crucially among which was the ratio of government spending to Gross Domestic Product (GDP). With a view to attaining a longterm balanced budget for all governments, the threshold of acceptable annual deficit was established as being 3\% of GDP. The introduction of a ceiling for maximum permissible government deficits apparently stood in the context of an understanding of "a 'golden rule': government indebtedness is admissible, but only to cover government investment, not current expenditure" (Sanchis i Marco, 2014: 23).

The EDP belongs to the 'corrective arm' (Tutty, 2012: 12) of the SGP, being a procedure to lead a state facing excess deficit back into greater fiscal discipline. The procedure, not untypical for EU procedures, combines supranational and intergovernmental bodies of governance (see Seikel 2016). The European Commission, upon receiving macroeconomic data from the member states, makes a recommendation to the ECOFIN Council (representing the member states) to start an EDP in case there is indication that the stability criteria are not fulfilled. The council then votes over that recommendation. In case of approval of the recommendation, the commission and council substantiate their criticisms and indicate general macroeconomic directions to be observed as well as deadlines for the state in question to take action and to change the situation. In the case of a member state repeatedly failing to meet the set criteria and the deadlines, the Council may issue a fine of up to $2 \%$ of GDP. So far, no state in an EDP has ever been effectively fined (Cohen, 2012: 692) but, as we will see, the EDP's effects on the articulation of sovereignty operate prior to any sanction (for a related argument, see de Goede, 2012: 48).

The EDP is an instrument designed to work in two directions. Being the 'corrective' element of a device for the 'surveillance' of a member state's annual ratio of spending in relation to the state's GDP, its first function is to work toward fiscal and economic convergence across the Eurozone and the EU. In this respect, the EDP is part of a device serving economic development and the deepening of European economic integration. Its second, more indirect function, however, is related to the containment of debt crisis contagion across EMU member states. The EDP's rationale is to lend credibility to the implementation of the Article 104B (noncross lending clause as part of the Treaty of Maastricht), which in turn is meant to lend credibility to the non-contagion of debt crises from state to state across Europe (Sanchis i Marco, 2014: 20). Therefore, the EDP can be regarded as an instrument meaning to serve economic convergence as well as financial signaling to the non-EU world.

Since its inception, the EDP has gone through a number of changes. These pertain, for instance, to the introduction of more flexible criteria governing the decision on the establishment of the existence of a state's excessive deficit in 2005. Referring to exceptional circumstances for which the respective state cannot be held responsible (like growth stalling due to international or global economic dynamics), these changes were proposed along with an extension of the SGP threshold criteria from annual spending deficit (3\% of GDP) to government debt ratio (60\% of GDP). Further still, fiscal surveillance was recalibrated in light of changes to the EU project more broadly:

The surveillance of fiscal policies will be encompassed in a broader perspective in the sense that economic and budgetary policies need to set the right priorities towards economic reforms, innovation, competitiveness and strengthening of private investment and consumption linking them to the wider macroeconomic goals of the EU, including the Lisbon strategy. (Sanchis i Marco, 2014: 25, original italics) 


\section{New regulations in reaction to the EMU debt crisis}

It was, however, only with the global financial crisis and its spillover into the Eurozone debt crisis, that even more profound changes were made to the EDP. These changes, according to Daniel Seikel (2016: 1403), "add up to one integrated macroeconomic governance regime for the Eurozone".

Very briefly summarized, the new regulations introduced by the Treaty on Stability, Coordination and Governance in the Economic and Monetary Union (TSCG, also called the 'Fiscal Compact', cf. Staehr, 2012; Mortensen, 2013) and by additional agreements since 2011 referred to as the 'Six Pack' and 'Two Pack' regulations, amount to the following. The Fiscal Compact, actually referring to that part of the TSCG that commits to balanced budgets in the contracting parties and to a strengthening of the EDP (de Haan et al., 2012: 6), has been identified as the core element of the recent reforms of supranational economic governance in the EU, which put budget frugality and fiscal discipline at center stage (Seikel, 2016). This is to be achieved by three different sets of surveillance and sanctioning procedures targeted toward disciplining the macroeconomic strategies of the member states: first, excessive deficit - that is, the EDP, now operating according to a changed procedural logic (see below); second, macroeconomic imbalances; and third, functionality of financial system (the last of which has its own surveillance and sanctioning procedures, see Tutty, 2012).

Of these, the EDP is the oldest mechanism, as it was already in place in the original SGP, and can thus be taken to represent a constitutive rationality of supranational macroeconomic governance in the EU. The EDP now stretches not only over the 3\% deficit margin but also over the 60\% government debt ratio introduced in 2005 (Seikel, 2016: 1404). Thus, while government debt had already been assigned an upper limit in the 2005 reforms, it could now also serve as a cause for starting an EDP. Even given its history of not having resulted so far in a single fine, today the EDP can be regarded as a core mechanism of a supranational economic regime that governs the overall fiscal conditions of EU member states: "The overall budgetary position is heavily circumscribed by the Treaty requirement for a structural budget deficit of no more than $0.5 \% / 1 \%$ of GDP and the requirement to get the debt ratio moving towards $60 \%$ by one-twentieth of the gap each year" (Tutty, 2012: 15).

Observers debate the question of whether these recent developments in the economic governance of the EU indicate a shift towards more supranationalism or more intergovernmentalism (see Gocaj and Meunier, 2013; Vilpišauskas, 2013; Donnelly, 2014; Hennessy, 2014; Mortensen, 2013). In this regard, a compelling case has been made that, even as governance keeps operating through an interlocking of supranational and intergovernmental bodies, the recent changes have taken away power from the member states (represented in the ECOFIN council) and shifted it toward the Commission. Daniel Seikel (2016) has argued that the new procedure of using 'reverse qualified majority voting' (RQMV) in the adoption of EC recommendations on the start of EDPs by the Council has left the Council members with less leeway to organize resistance against EC recommendations.

Originally, the SGP determined that recommendations of the Commission were dependent on the approval of a qualified majority of Euro-countries. The Six Pack reverses the decision-making mode: recommendations of the Commission automatically count as approved unless a qualified majority rejects the proposal within a period of only 10 days. (Seikel, 2016: 1405)

The Fiscal Compact, in its turn, broadens this new procedure and "eliminates the Member States' formal power to change recommendations with a qualified majority and extends the 
RQMV to all stages of the EDP, including the decision about whether an excessive deficit exists" (Seikel, 2016: 1405).

Often, then, the new regulations adopted in response to the crisis are estimated as strengthening the supranational level as a result of a "delegation of fiscal authority" at the national level (de Haan et al., 2012: 2), largely through the new RQMV procedures. However, the next subsection argues that these new regulations may also be understood as a particular, debt-centered form of invocation of state sovereignty, in the sense of a modular sovereignty as conceptualized above.

\section{The EDP as a crystallization of modular sovereignty}

It has been confirmed variously in the literature that the new regulations aim at conditioning and disciplining state budgets along the lines of budget frugality, directing them towards austerity measures in case of an EDP (Regling, 2012; Mortensen, 2013; Seikel, 2016). With respect to absent market capitalization of government debt as in some recent cases, I have argued that this creates symbolically "collateralized polities" (which are urged to lay open their books and to expose their collateral [Langenohl, 2015]). The EDP might be conceived of as a milder version of such forced collateralization because it does not threaten states with letting them slip into default. Yet, governments under EDP must provide minute details to the EC and the Council on a regular and frequent basis. For example, with the so-called Two Pack regulations "the legislation establishes a system of graduated monitoring, which includes regular reporting by the concerned Member State every 6 or 3 months". ${ }^{4}$ In such a way, the budgetary stocktaking is very profound. As the EDP record shows, the procedure has been, or is being, executed against 26 member states - virtually the totality of the EU. ${ }^{5}$ Given the increased ease with which the process can be started by the EC under conditions of reverse qualified majority voting, no decrease in such procedures is to be expected (Seikel, 2016: 1411). Given that the EDP, in addition to covering deficit surveillance, now also extends to debt surveillance, it can be suggested that the EDP, within the new regulatory ramifications of the Fiscal Compact, the Six Pack, and the Two Pack, is a device constituting the preconditions for a new normal of supranationally surveilled and sanctioned government indebtedness in the EU.

In what follows, I want to lay out the consequences for a new regime of sovereignty crystallizing around indebted states, inserting the new EDP regulations into the conceptual framework of the modular notion of sovereignty elucidated above. Along these lines, I will argue that indebted sovereignty in the EU may be conceptualized as a modality of sovereign power that has multiple sources, follows heterogeneous dynamics, and which can be combined differently, and with different results. First, the EDP procedure is in actuality a form of address of member states by the supranational level that presupposes their sovereignty over their fiscal affairs. On the one hand, "The detailed measures in the budget are still a matter for the Member State but the budget must be submitted in draft form to the Commission and must be amended if the Commission considers that there is serious noncompliance with commitments" (Tutty, 2012: 15). On the other hand, the EDP can only be initiated if there is no indication that the present budget and deficit situation has been brought about by forces outside of the government's reach:

The excess of a government deficit over the reference value of $3 \%$ is considered exceptional when resulting from an unusual event outside the control of the Member State concerned and which has a major impact on the financial position of the general government, or when resulting from a severe economic downturn. (Tutty, 2012: 11). 
While this regulation has been reproached as eroding the 'automaticity' and thus endangering the enforcement and strictness of the EDP (de Haan et al., 2012: 4), from the point of view of the attribution of sovereignty to a member state, the start of an EDP locks in a state's sovereignty, in the sense of the attribution of the capacity to cause, and also to end, a problematic deficit situation. The start of an EDP addresses member states in the sovereignty of being functionally able to make and enforce budget decisions.

Second, in an EDP, member states are addressed in a similar way that a 'Leviathan' would be addressed, namely, as an institution governing society and economy. However, this empirical address comes from 'above', namely from the supranational (together with the intergovernmental) level, unlike in the fictional address in the Leviathan coming from society 'below', according to Hobbes's foundational political-theoretical scene. In other words, the EDP addresses member states via their governments as being entities separate from 'their' societies and national economies. This contributes to the invocation of an understanding of sovereignty along the lines of Agamben's conception of sovereignty as a norm-setting decision of last resort, apart from juridical restrictions (cf. Amoore, 2013: 13-18).

Third, while the first two moments through which the modular sovereignty of indebted states is constituted point in the direction of Amoore's and Agamben's discussion of sovereignty as having the capacity to decide and to set norms, the third sovereignty effect of an EDP reveals its mingling with notions of biopolitical, governmental rationality as highlighted by Langley. This is the case when the EC's and Council's recommendation and norm-setting refer to processes of economic and societal dynamics of the member state in question that can cancel or modify the EDP's strict automatism.

For instance, in the case of the ongoing EDP against Spain started in April 2009 (ECOFIN 233), the Council adapted its recommendations repeatedly to the macroeconomic, socialstructural and demographic circumstances evolving in the course of the crisis, oscillating back and forth between an enforcement of the stability criteria and their suspension due to biopolitical rationalities of the population's 'well-being' and societal 'cohesion'. In July 2016, the Council decided that "no effective action has been taken by Spain in response to the Council Recommendation of 21 June 2013" in a legislative act that did not at all refer to societal dynamics (ECOFIN 675), followed by a "notice to Spain to take measures for the deficit reduction judged necessary in order to remedy the situation of excessive deficit" on 2 August, 2016 (ECOFIN 742). Yet, three days later, and responding to a 'reasoned request' by the Spanish government issued on 13 July, the Council then made a "decision on imposing a fine on Spain for failure to take effective action to address an excessive deficit" which cancelled the $2 \%$ fine with a view to threats to "social cohesion" (ECOFIN 745):

\footnotetext{
While some of the measures taken in recent years had a negative direct impact on the public finances, they may contribute to growth and employment in the medium to long term, and in turn to the sustainability of public finances. Social security contributions, exemptions and rebates contributed to the persistent general government deficit, but to some extent supported social cohesion by targeting lower income earners, less qualified workers and new permanent contracts. (ECOFIN 745: 6)
}

This means that the state government, although addressed as sovereign in its macroeconomic decisions, is implicitly legitimated in its indebted sovereignty by the requirements of securing the 'well-being' of the population. What results from this constellation is a hybrid, seemingly contradictory, address of the state as unconditionally sovereign and yet conditioned by biopolitical rationalities that are concerned with the 'security' of the population. 
The fourth aspect to modular indebted sovereignty relates to the economic rationalities along whose lines EDP processes are conducted. The economic criteria on which the EC and the Council rely are set up in expert commissions both in the national governments and on the EU level. The sequence of mutual information and conversation between these bodies is highly regulated in the EDP. For instance, disagreement as to the validity and salience of these data is procedurally channeled into 'reasoned requests' through which the member states can make claims to stop or alter the conduct of an EDP. This was done by the Banco de Espana (n.d.) in a 'Methodological note', which, among other arguments, highlighted "[d]ifferent concepts of indebtedness" (Banco de Espana, n.d.: 1) as justification for reconsidering the fine imposed on Spain. Thus, while the EDP presupposes a member state's fiscal sovereignty, concurrently expert bodies and procedural routines are put in place that preordain the definition of the 'problematization' (sensu Foucault, cf. Langley, 2015: 19-20), and 'frame' (Callon, 1998) and condition any sovereign decision by the government. Through the introduction of economic expertise to frame budget and debt problems, the state government is put on par with the supranational and intergovernmental bodies of the EU, as the negotiations over specific conditions and over the turns of the EDP itself do no follow a sovereign logic but a bargaining logic. The demand to lend to the EDP a greater degree of automaticity, and thus to "depoliticize" it (de Haan et al., 2012: 2), finds a praxeological correlate in technical scientific elaborations on both a member state's budget and on the measures it has (or has not) adopted, as recommended by the Commission and the Council.

So, a point of convergence of these seemingly conflicting logics of sovereignty is the heterogeneous, distributed, and indeed modular character of sovereignty itself, as outlined by both Amoore (the heterogeneity of the process of the 'decision') and by Langley (the heterogeneity of the different modalities of power, leading to interactions especially between sovereign and governmental power). Of course, the EU's political rationality relies as such on an institutional multiplication of sites of sovereignty on the national, intergovernmental, and supranational levels, a point that has been intensively discussed in EU-related political research (for an influential position see Scharpf, 1988, 1999; cf. Seikel, 2016: 1401-402). Yet, in light of the arguments regarding the conceptualization of sovereignty developed here, we can locate the heterogeneity of state sovereignty in its oscillation between a state being addressed as sovereign vis-à-vis its population, a state being conditional upon biopolitical dynamics within that population, and a state being circumscribed by scientific economic rationalizations.

The heterogeneity of the state's different modalities of sovereignty can most clearly be seen when we turn, finally, to the question of how security concerns figure within it. Security is invoked in two ways. First, the EC and the Council make reference to the EDP in order to stop processes that can become dangerous for EU and EMU integration as a project from the very start - a point made by Sanchis i Marco (2014), who argues that the EDP response's rationality not least consists in symbolically fostering attempts to fight the contagion of fiscal and debt crises over the Eurozone. This first invocation of security mostly takes the semantic shape of an enumeration and analysis of the different sorts of 'risk' that threaten the fiscal stability of the state. Yet, the notion of 'risk' also figures as an overarching construct to frame scenarios in which the state and the 'caretaker' government would not meet the criteria of the SGP or fail to implement the Council's related recommendations, namely, as "risk of noncompliance" (ECOFIN 675: 4). Second, security is invoked with respect to biopolitical rationality - that is, the securing of the population's 'well-being' and society's 'cohesion'.

Here, we can put to use the earlier discussion of Hobbes and around the anthropology of debt. The double notion of security as a category of invocation - the political, vital security of 
the $E(M) U$ and the biopolitical, no less vital security of the population - rearticulates a contractualist reading of Hobbes's notion of sovereignty. Its specificity resides in the state assuming a governance positionality vis-à-vis its own population that shuttles between a concern for budget 'risk' and a concern with 'social cohesion'. These two concerns enter into a tense relationship. On the one hand, the state is addressed as a seat of sovereign fiscal decision and as separate from society, and on this basis is held accountable for its budget with a view to securing the political existence of the EMU and EU. The state, in this constellation of modular sovereignty, is treated as an abstraction from society, thus replaying the Hobbesian abstraction from social structures and interests in the state. This state has to 'forget' (cf. Amoore 2013: 76) about its population and its hierarchies in order to assume sovereign power. On the other hand, the state is also addressed as responsible for the biopolitical security of its population, and thus has to reflect on its fiscal positionality within economy and society. The presence of biopolitical rationality constrains Hobbesian sovereignty, thus charging the state with accounting for social security as part of 'well-being'. Within the EMU context of the EDP, the biopolitical rationality can be used to cancel out the demands governed by Hobbesian rationality, like when arguments of the necessity to secure social cohesion are used to ameliorate strict calls for budget frugality. Finally, forms of macroeconomic knowledge and representations of society and economy intervene in the framing of the budget and the problematization of debt.

\section{Conclusion: Modular debt governance in the EU}

The last section has shown how the EDP positions the EU indebted member state in multiple ways as the seat of sovereignty, yet with different implications regarding the precise articulation of such sovereignty. This is a significant result in itself, given current preoccupation with the question of whether the seat of power in the EU and EMU is shifting toward the national or the supranational levels of governance in the wake of the sovereign debt crisis. Such debates are limited to the extent that they only distinguish between different domains of sovereignty, and not between its different modalities. These modalities - and their dynamism - bear an important but complex relationship to contractualist thought, inasmuch as the imaginary of the contract enables political and financial governance structures that are based on an effacement of the structuration and hierarchization of their social substrate.

The multiple and modular accreditation of the indebted state as sovereign in the EDP does not position the state as the old and new nexus of sovereign power. Rather, the accreditation of indebted state sovereignty is entangled with governance demands and financial heuristics put before the state. Thus, the indebted state may be addressed as a 'Leviathan', responsible for governing its economy and society from a position of sovereign separation from that economy and society, and in disregard of structures, cleavages and hierarchies that shape them. Conversely, the indebted state may be addressed as responsible for the 'well-being' of its population, that is, on the grounds of a biopolitical rationality justifying sovereign decisions. Lastly, the indebted state is allowed to articulate its sovereignty vis-à-vis the supranational center on the basis of a macro-economic and financial rationality that is preordained in expert discourse and exchange across the different governance levels. We are witnessing a composite form of debt governance based on modular articulations of state sovereignty.

The sovereign accreditation of the indebted state does in no way herald a return to 'national sovereignty' in the EU. Instead, that accreditation works through the sovereign state as a catalyst for measures to be formulated and taken. Thus, the attribution of sovereignty has 
to be distinguished from the question of where power resides, because it is ultimately a question of the recombination of different modalities of power connecting the supranational and state levels of governance with the population and the governmental rationality through which it is approached.

In conclusion, I would like to summarize the conceptual contributions of this article. First, and on the most general level, it has demonstrated the capacities of a complex and modular notion of sovereignty. While, on the one hand, these capacities have been developed through a discussion of authors whose conceptions of sovereignty point away from the state, it has been suggested that they can be fruitfully projected onto the state as the addressee of demands to act in a sovereign way. In other words, it is possible to use the analytics of a complex notion of sovereignty, developed in a bid to detach the notion of sovereignty from the state, in order to redirect these analytics back to the state as the seat of a complex, heterogeneous, and highly modular modality of sovereignty. This is also important in the context of the literature on the security-finance nexus, as it demonstrates how the state can be regarded as a catalyst in modulating interchanges between security and financial logics.

Second, the accreditation of the state as the seat of both political legitimacy and financial security, highlighted by Boy $(2014,2015)$, might be even better understood in its specificity when accounting for the social substrates presupposed, and at the same time denied, in such accreditation. The critique of liberal-contractualist notions of sovereignty, as Foucault's reading of Hobbes indicates, redirects attention toward the question of how the security and safety of some members of society can become generalized into, as well as framed and enabled by, a universalizing claim to sovereign power - of course, at the expense of other members' interests. In this light, we should add the dimension of universalizing claims to (political and financial) security arising from particular interests to contemporary research on the securityfinance nexus.

Finally, the article dissected the EDP as a mechanism that is significant for conceptually interrelating finance and security more generally. Within the EU, the indebted state becomes constituted as a flexible hinge for the articulation of conflicting and contradictory articulations of modular sovereignty that aim at different understandings of what actually has to be secured. Thus, while the governance of the current sovereign debt crisis might be interpreted as a restriction on member states' sovereign powers (Langenohl, 2015), the EDP rather effects an inflation and a (potentially contradictory) accumulation of different components of sovereign accreditation. The state may be held liable for both the financial security of its debts through imposing budget restrictions on its population, and for the financial 'wellbeing' and 'social cohesion' of its population; it may also become the lever of economic experts formulating norms regarding financial security in a pre-juridical realm. "Governing by debt" (Lazzarato, 2015), in the case of the EU, clearly has a propensity to revalue the state as the seat of sovereignty. Even so, this is a sovereignty that is neither unitary nor unconditional.

\section{Acknowledgments}

I am indebted to the editors of this special issue, to two anonymous reviewers and to Carola Westermeier for helpful and inspiring comments on earlier drafts of this article. The research on which the article is based was enabled by the Collaborative Research Centre/Transregio 138 project Dynamics of Security: Forms of Securitization in Historical Perspective (Universities of Giessen and Marburg), funded by the German Research Foundation. 


\section{Notes}

1. This was slightly different, if not totally discontinuous, in the case of war bonds, when investors had to be urged to buy these bonds in order to secure the state (yet also themselves), both financially and politically (cf. Kolb, 2011: 1-13).

2. Here I go beyond Best's (2017: 378) recent reconstruction of security- and economy-related exceptionalism as "defining the limit of normal politics, suspending the norm (or the law), and putting the exception into practice", which lacks the dimension of accreditation.

3. Amoore (2013: 66) refers to security norms composed of multiple utilities - not only that of detecting a trespass, but also that of modifying the definition of what counts as normal - as modular.

4. European Commission: Excessive Deficit Procedure under the Two Pack regulation. Available at: <https://ec.europa.eu/info/business-economy-euro/economic-and-fiscal-policy-coordination/eueconomic-governance-monitoring-prevention-correction/stability-and-growth-pact/corrective-armexcessive-deficit-procedure/excessive-deficit-procedure-under-two-pack-regulation_en>. Accessed 8 August 2017.

5. European Commission: The corrective arm/Excessive Deficit Procedure. Available at: <https://ec.europa.eu/info/business-economy-euro/economic-and-fiscal-policy-coordination/eueconomic-governance-monitoring-prevention-correction/stability-and-growth-pact/corrective-armexcessive-deficit-procedure_en>. Accessed 9 August 2017.

\section{References}

Adloff, F. (2016) Gifts of Cooperation, Mauss and Pragmatism. London: Routledge.

Adloff, F. and Mau, S. (2005) Giving social ties, reciprocity in modern society. European Journal of Sociology, 47(1): 93-123.

Agamben, G. (2002) Homo Sacer: Die souveräne Macht und das nackte Leben. Frankfurt: Suhrkamp. Agamben, G. (2005) State of Exception. Chicago, IL: Chicago University Press.

Amoore, L. (2013) The Politics of Possibility: Risk and Security Beyond Probability. Durham, NC: Duke University Press.

Andromidas, D. (2015) Greece asserts sovereignty; the debt cannot be paid. Executive Intelligence Review, 42(7): 16-19.

Banco de Espana (n.d.) Methodological note: General government debt compiled according to the methodology of the Excessive Deficit Procedure (EDP). Available at: $<$ https://www.bde.es/webbde/en/estadis/infoest/htmls/notamet_pde.pdf $>$. Accessed 9 August 2017.

Best, J. (2017) Security, economy, population: The political economic logic of liberal exceptionalism. Security Dialogue, 48(5): 375-92.

Bourdieu, P. (1997) Marginalia: Some additional notes on the gift. In: Schrift, A.D. (ed.) The Logic of the Gift: Toward an Ethic of Generosity. London: Routledge, 231-41.

Boy, N. (2014) Öffentlichkeit als public credit. In: Langenohl, A. and Wetzel, D.J. (eds.)

Finanzmarktpublika: Moralität, Krisen und Teilhabe in der ökonomischen Moderne. Wiesbaden: Springer VS, 301-17.

Boy, N. (2015) Sovereign safety. Security Dialogue, 46(6): 530-47.

Caillé, A. (2008) Anthropologie der Gabe. Frankfurt: Campus.

Callon, M. (1998) An essay on framing and overflowing. In: Callon, M. (ed.) The Laws of the Market. Oxford: Blackwell, 244-69. 
Cohen, B.J. (2012) The future of the euro: Let's get real. Review of International Political Economy, 19(4): 689-700.

Dean, M. (1994) Critical and Effective Histories: Foucault's Methods and Historical Sociology. London: Routledge.

de Goede, M. (2012) Speculative Security: The Politics of Pursuing Terrorist Monies. Minneapolis, MN: University of Minnesota Press.

de Haan, J. et al. (2012) Beyond the Fiscal Compact: How Well Designed Eurobonds May Discipline Governments. Available at:

<http://www.szgerzensee.ch/fileadmin/Dateien_Anwender/Dokumente/Conferences/Swiss_Debt _Brake/JDeHaan_Nov_2012.pdf>. Accessed 22 August 2017.

Donnelly, S. (2014) Power politics and the undersupply of financial stability in Europe. Review of International Political Economy, 21(4): 980-1005.

ECOFIN 233 (7904/09) Council recommendation to Spain with a view to bringing an end to the situation of an excessive government deficit. Brussels: Council of the European Union, 6 April 2009.

ECOFIN 675 (10793/16) Council decision establishing that no effective action has been taken by Spain in response to the Council Recommendation of 21 June 2013. Brussels: Council of the European Union, 11 July 2016.

ECOFIN 742 (11552/16) Council decision giving notice to Spain to take measures for the deficit reduction judged necessary in order to remedy the situation of excessive deficit. Brussels: Council of the European Union, 2 August 2016.

ECOFIN 745 (11555/16) Council implementing decision on imposing a fine on Spain for failure to take effective action to address an excessive deficit. Brussels: Council of the European Union, 5 August 2016.

Foucault, M. (2003) Society Must Be Defended: Lectures at the Collège de France, 1975-76. London: Penguin.

Foucault, M. (2007) Security, Territory, Population: Lectures at the Collège de France, 1977-1978. Basingstoke: Palgrave.

Gocaj, L. and Meunier, S. (2013) Time will tell: The EFSF, the ESM, and the Euro crisis. Journal of European Integration, 35(3): 239-53.

Graeber, D. (2001) Toward an Anthropological Theory of Value: The False Coin of Our Own Dreams. Basingstoke: Palgrave, 151-63.

Graeber, D. (2011) Debt: The First 5,000 Years. New York, NY: Melville House.

Hebekus, U., Matala de Mazza, E. and Koschorke, A. (eds.) Das Politische: Figurenlehre des sozialen Körpers nach der Romantik. München: Fink.

Hennessy, A. (2014) Redesigning financial supervision in the European Union (2009-2013). Journal of European Public Policy, 21(2): 151-68.

Kindleberger, C.P. (1996) Manias, Panics, and Crashes: A History of Financial Crisis. Third edition. New York, NY: John Wiley \& Sons.

Kolb, R.W. (2011) Sovereign Debt: From Safety to Default. New York, NY: John Wiley \& Sons.

Langenohl, A. (2015) Collateralized polities: The transformation of trust in sovereign debt in the wake of the Eurozone crisis. Behemoth: A Journal on Civilisation, 8(1): 67-90.

Langley, P. (2013) Toxic assets, turbulence and biopolitical security: Governing the crisis of global financial circulation. Security Dialogue, 44(2): 111-26.

Langley, P. (2015) Liquidity Lost: The Governance of the Global Financial Crisis. Oxford: Oxford University Press.

Lazzarato, M. (2015) Governing by Debt. Cambridge, MA: MIT Press. 
Manow, P. (2011) Politische Ursprungsphantasien: Der Leviathan und sein Erbe. Konstanz: Konstanz University Press.

Mauss, M. (1954) The Gift: Forms and Functions of Exchange in Archaic Societies. New York, NY: W.W. Norton.

Miller, P. and Rose, N. (1990) Governing economic life. Economy and Society, 19(1): 1-31.

Mortensen, J. (2013) Economic Policy Coordination in the Economic and Monetary Union: From Maastricht via the SGP to the Fiscal Pact. CEPS Working Documents, No. 381.

Neocleous, M. (2007): Security, liberty and the myth of balance: Towards a critique of security politics. Contemporary Political Theory, 6(2): 131-49.

Peebles, G. (2008) Inverting the panopticon: Money and the nationalization of the future. Public Culture, 20(2): 233-65.

Priddat, B.P. (2014) Schuld, Schulden, Kredit: Der Beginn ökonomischer Moderne. In: Macho, T. (ed.) Bonds: Schuld, Schulden und andere Verbindlichkeiten. München: Fink, 95-104.

Regling, K. (2012) Europe's response to the European sovereign debt crisis. Presentation at the Anders Chydenius Free Trade Seminar, Kokkola, 8 June.

Sanchis i Marco, M. (2014) The Economics of the Monetary Union and the Eurozone Crisis. Cham: Springer, 13-28.

Scharpf, F.W. (1988) The joint-decision trap: Lessons from German federalism and European integration. Public Administration, 66(3): 239-78.

Scharpf, F.W. (1999) Governing in Europe: Effective and Democratic? Oxford: Oxford University Press.

Seikel, D. (2016) Flexible austerity and supranational autonomy: The reformed Excessive Deficit Procedure and the asymmetry between liberalization and social regulation in the EU. Journal of Common Market Studies, 54(6): 1398-416.

Skinner, Q. (2008) Hobbes and Republican Liberty. Cambridge: Cambridge University Press.

Staehr, K. (2012) The Fiscal Compact: Implementation, Enforcement and Efficacy. Tallinn: Tallinn University of Technology.

Tutty, M.G. (2012) Reforming European Economic Governance: The European Semester and Other Recent Developments. Dublin: The Institute of International and European Affairs.

Vilpišauskas, R. (2013) Eurozone crisis and European integration: Functional spillover, political spillback? Journal of European Integration, 35(3): 361-73. 